American Journal of Applied Sciences 7 (8): 1079-1082, 2010

ISSN 1546-9239

(C) 2010 Science Publications

\title{
Buffering Capacity of Fast-Growing Species and Curing Time of UF Resin Modified With Zinc Borate and Monoammonium Phosphate
}

\author{
${ }^{1,2}$ Izran Kamal, ${ }^{1}$ Koh Mok Poh, ${ }^{1}$ Tan Yu Eng, ${ }^{3}$ Xue Jun Ren, ${ }^{2}$ Zaidon Ashaari, \\ ${ }^{2}$ Faizah Abood, ${ }^{4}$ Guenter Beyer and ${ }^{1}$ Khairul Masseat \\ ${ }^{1}$ Forest Research Institute Malaysia, 52109, Kepong, Selangor, Malaysia \\ ${ }^{2}$ Faculty of Forestry, University Putra Malaysia, 43400 Serdang, Selangor, Malaysia \\ ${ }^{3}$ School of Engineering, Liverpool John Moores University, Liverpool L3 3AF, UK \\ ${ }^{4}$ Physical and Mechanical Laboratories, Kapelwerk Eupen Ag, B-47000 Eupen, Belgium
}

\begin{abstract}
Problem statement: Occupying a suitable hot pressing time for particleboard fabrication seems very tricky for manufacturers of the wood-based panel. Longer or shorter pressing times can affect physical and mechanical properties of the produced particleboards and that is why extra care should be given on this matter. Longer pressing time can cause resin in a particleboard to over-cure whereas shorter pressing time can cause insufficient curing of the resin. Determination of hot pressing time is influenced by the type of filler and chemical used. The acidity or alkalinity of a filler and chemical can lengthen or shorten the time taken by the resin to cure. These parameters are usually assessed using buffering capacity test and curing time test. In this study, the two analyses were occupied to assess acidity or alkalinity of kenaf, Shorea macrophylla and Acacia mangium as well as the effect of fire retardants (zinc borate and monoammonium phosphate) to the curing rate of urea formaldehyde resin. Determine acidity or alkalinity of the wood particles through buffering capacity test. The effect of the fire retardants to the curing of Urea Formaldehyde (UF) resin was also studied. Approach: For buffering capacity test, the wood particles were extracted. Then, the extracts were separated into two parts. One part was tested with sodium hydroxide $(\mathrm{NaOH})$ and another part was tested with sulphuric acid $\left(\mathrm{H}_{2} \mathrm{SO}_{4}\right)$. Sodium hydroxide was added into the extracts until they reached $\mathrm{pH}$ 11. The other part was added with sulphuric acid until they reached $\mathrm{pH} 3$. The $\mathrm{pH}$ value was recorded each time $5 \mathrm{ml}$ chemicals added. The acidity of the plants was observed by looking at the volume of sulphuric acid needed to reduce their $\mathrm{pH}$ to 3 , whereas alkalinity was evaluated by looking at the volume of sodium hydroxide used to increase their $\mathrm{pH}$ to 11 . Curing times of UF resin added or not added with fire retardants were calculated in second (sec). Results: Buffering capacity study revealed that kenaf, Shorea macrophylla and Acacia mangium behaved similarly in alkali and acidic conditions. All the materials had less resistance towards acid than towards alkali. Kenaf had the greatest resistance towards alkali compared with the other two species. As an important processing parameter in particleboard fabrication, the curing time of the adhesive mixture with added fire retardants was studied in comparison with a control mixture (without fire retardant with a curing time of $140 \mathrm{sec}$ ). Those two fire retardants showed different effect on the curing time of the mixture. Zinc borate was found to delay the curing time by more than $100 \%$ compared with control mixture whereas, monoammonium phosphate increased the curing time by almost $60 \%$. The curing time for control mixture (without fire retardant) was $140 \mathrm{sec}$. Conclusion: Based on the testing results, some potential modifications to improve the curing time were discussed to avoid short curing time to improve the manufacturability of the material systems.
\end{abstract}

Key words: Buffering capacity, curing time, kenaf, Shorea macrophylla, Acacia mangium

\section{INTRODUCTION}

With the rate of deforestation each year increase rapidly, it is becoming increasingly important for particleboard manufacturers are urged to find alternative raw materials to ensure continuous particleboard production in order to meet market demand. One feasible approach is to use, raw materials that can grow and achieve suitable height or girth within a short period of time. Kenaf, engkabang and

Corresponding Author: Izran Kamal, Forest Research Institute Malaysia, 52109, Kepong, Selangor, Malaysia 
Acacia mangium have been found to be potential suitable candidates for these requirements. However, the performance of the materials/species at different conditions and effects of key processing parameters have to be established to prove their suitability for particleboard. There are many factors that need to be considered in producing particleboard such as particle geometry, particle type, raw material type, binder type and type of chemical that is intended to be applied into the particleboard (either for wood preservation or fire protection). The alkalinity and the acidity of the raw material are also important factors that need to be considered, especially when the particleboard production is involving $\mathrm{pH}$-sensitive binder such as acid-curing Urea Formaldehyde (UF) and alkali-curing Phenol Formaldehyde (PF).

The alkalinity or acidity of the raw material is known to affect/influence the curing of the binder (Paridah et al., 2001). The rate of polymerization of the binder may increase or decrease with different raw materials and additives, directly influencing/changing the hot pressing time and temperature during the fabricating-particleboard process (Paridah et al., 2001). Longer or shorter hot pressing may result in adverse effect on the physical and mechanical properties of particleboard, due to insufficient or overcuring of the binder and improper internal bonding between the binder and particles (Izran et al., 2009a). The modification on the pressing time can be achieved in two ways. The first modification can be done by increasing the hot pressing temperature and shortening the pressing time or decreasing the hot pressing temperature and lengthening the pressing time. The second one is by adding alkali or acidic buffer to neutralise the raw material acidity or alkalinity to achieve an optimum pressing time to make the binder in the particleboard cure sufficiently. The acidity or alkalinity can be measured by doing buffering capacity test in which, the alkalinity or acidity of a raw material was assessed by determining the volume of acid or alkali required to change the $\mathrm{pH}$ of the raw material to $\mathrm{pH} 11$ or $\mathrm{pH} 3$. The higher the volume of alkali needed to move the $\mathrm{pH}$ of the raw material to $\mathrm{pH} 11$, the higher the acidity of the raw material, while the higher the volume of acid to achieve $\mathrm{pH} 3$, the higher the alkalinity.

The raw material acidity and alkalinity were not the only factors affecting the curing of binder. In the production of particleboards, chemicals are usually incorporated into mixture to improve certain functional properties of the materials (e.g., fire retardants and wood preservatives). These additives can cause similar effects on the curing process similar to the influences of the acidity and alkalinity of the raw materials (Izran et al., 2009b; Zaidon et al., 2008a; 2008b). For any new materials systems, the effect of these factors has to be determined to establish the optimum materials and processing parameters. This study aims to measure the alkalinity or acidity of three fast growing species i.e., kenaf (Hibiscus cannabinus), engkabang (S. macrophylla) and A. mangium and effects of fire retardant salts (i.e., zinc borate and monoammonium phosphate) on the curing of UF resin. The findings of the study will be used for determining hot pressing time for producing particleboards made from the three fast growing species treated with boric-based and phosphoric-based fire retardants (zinc borate and monoammonium phosphate).

\section{MATERIALS AND METHODS}

Sources of three fast growing species: Three fast growing species were used in the study. Kenaf was supplied by Lembaga Tembakau Negara (LTN), logs of S. macrophylla were brought by Sarawak Forest Department and A. mangium was obtained from Asia Prima, Mentakab and Aramijaya, Ulu Selidi, Johore.

Sample preparation: The wood species were firstly flaked using knife ring Flaker located at the Wood Composite Workshop, Forest Research Institute Malaysia (FRIM). Then, they were screened to various sizes of particles, however only particles with 1 and 2 $\mathrm{mm}$ size were taken for the test. The particles were brought to the Wood Composite Test Laboratory for extraction. The extraction was done by mixing $10 \mathrm{~g}$ of particles from each species with $100 \mathrm{~g}$ water in flasks separately. The flasks were then placed on a hot plate for refluxing process. One hour of refluxing was sufficient to extract the particles. The particle-water mixtures were filtered using a filtering glass crucible which was equipped with an aspirator vacuum to assist in obtaining more extract. The extracts were diluted to $250 \mathrm{ml}$ with distilled water and were cooled to ambient temperature before proceeding to the second stage for titration.

Buffering capacity of the fast growing species: Each extract was divided into six parts by using six $15 \mathrm{~mL}-$ small beakers. Sodium hydroxide was used to test acidity where as hydrochloric acid was for alkalinity testing. Three parts of the extract were titrated manually with $0.025 \mathrm{~N}$ sulphuric acid $\left(\mathrm{H}_{2} \mathrm{SO}_{4}\right)$ until they reached $\mathrm{pH}$ 3.0. These steps were repeated using the remaining three parts with $0.025 \mathrm{~N}$ sodium hydroxide $(\mathrm{NaOH})$ until they reached $\mathrm{pH}$ 11.0. The $\mathrm{pH}$ values were 
recorded for every $5 \mathrm{ml}$ of titration. The total volume of $\mathrm{NaOH}$ or $\mathrm{H}_{2} \mathrm{SO}_{4}$ was calculated at the end of the test. A table was formed to quantitative analysis of the changes of the $\mathrm{pH}$ values.

Curing time of $\mathrm{ZBr}$ and MAP-mixed UF resin: Zinc Borate (ZBr) and Monoammonium Phosphate (MAP) were purchased from Euroscience Sdn. Bhd. Urea Formaldehyde (UF) resin was given by Malayan Adhesive Chemicals (MAC). The mixtures of fire retardants and UF resin were used as a binder for producing fire retardant-treated particleboard. To achieve a density of $700 \mathrm{~kg} \mathrm{~m}^{-3}, 79 \mathrm{~g}$ of UF resin, $12 \mathrm{~g}$ hardener and $17 \mathrm{~g}$ wax were required to produce the $700 \mathrm{~kg} \mathrm{~m}^{-3}$ particleboard. The UF resin, hardener and wax were mixed in the same batch and divided into two portions for studying the effects of different fire retardant additives. One portion was mixed with $10 \%$ w/w $\mathrm{ZBr}$ and another portion was mixed with $10 \% \mathrm{w} / \mathrm{w}$ MAP. The $\mathrm{pH}$ of the UF-fire retardant mixtures was measured using whatman full range $\mathrm{pH}$ determination study. Each portion of the mixture was evenly distributed into four test tubes with $10 \mathrm{ml}$ of the mixture per tube.

At the same time, $80 \mathrm{ml}$ of water was poured into a $100 \mathrm{ml}$ beaker and it was heated on a hot plate until the water reached boiling temperature $\left(100^{\circ} \mathrm{C}\right)$. To make sure that temperature of the water was accurately $100^{\circ} \mathrm{C}$, the temperature was measured with a thermometer. The test tubes filled with resin-fire retardant mixtures were then soaked into the water once the water reached boiling temperature. The test tubes and their contents were submerged in the boiling water and stirred until the mixtures hardened and gelled. The test tubes were held by a retort holder with one test tube was soaked at a time.

\section{RESULTS}

Buffering capacity test: The buffering capacity of the three fast growing species is presented in Table 1. As shown in Table 1, when all three species were exposed to alkali condition, kenaf was found to have the strongest resistance towards alkali as it required largest volume of $\mathrm{NaOH}$ to reach $\mathrm{pH}$ 11. S. macrophylla and A. mangium presented quite similar trend with slightly different value under the same condition. The change in $\mathrm{pH}$, however, was greater in kenaf compared with S. macrophylla and A. mangium. Similar pattern of results was recorded when the three materials were exposed to acidic condition. Even though kenaf was found to be less resistance towards acid (compared with the result when it was exposed to alkali condition), it still exhibited the greatest resistance towards acid over the other two species).
Table 1: Buffering Capacity of kenaf, S. macrophylla and A. mangium

\begin{tabular}{|c|c|c|c|c|}
\hline Species & $\begin{array}{l}\text { Vol. of } 0.025 \\
\mathrm{~N} \mathrm{NaOH}(\mathrm{mL}) *\end{array}$ & $\mathrm{pH}$ & $\begin{array}{l}\text { Vol. of } 0.0 \\
\mathrm{~N} \mathrm{H}_{2} \mathrm{SO}_{4}\end{array}$ & $\mathrm{pH}$ \\
\hline \multicolumn{5}{|l|}{ A. mangium } \\
\hline $\begin{array}{l}\text { Average } \\
\text { S macronhulla }\end{array}$ & 5.70 & 7.06 & 1.28 & 2.58 \\
\hline Average & 1.05 & 7.41 & 1.18 & 2.98 \\
\hline Kenaf & & & & \\
\hline Average & 39.30 & 10.1 & 4.00 & 3.45 \\
\hline
\end{tabular}

Table 2: Curing time of UF resin mixed with zinc borate or monoammonium phosphate

\begin{tabular}{lcc}
\hline Samples & Curing time $(\mathrm{sec})^{*}$ & $\mathrm{pH}$ \\
\hline $10 \%$ ZBr-UF & 375 & 10 \\
$10 \%$ MAP-UF & 20 & 4 \\
Control & 140 & 7 \\
\hline
\end{tabular}

*: Means of three samples

Determination of curing time: The average times taken for $10 \% \mathrm{ZBr}$ - mixed resin and MAP-mixed resin were 375 and $20 \mathrm{sec}$, with the $\mathrm{pH}$ of the mixtures was 10 and 4 respectively (Table 2). As for the control samples, the average curing time was $140 \mathrm{sec}$ and the $\mathrm{pH}$ was neutral.

\section{DISCUSSION}

Buffering capacity test: The results of buffering capacity test suggest that $S$. macrophylla would cause acid-curing resin such as UF resin to cure faster. More buffer is needed to make S. macrophylla becomes less resist to alkali than that for A. mangium and kenaf.

Determination of curing time: According to the resin description provided by Malayan Adhesive Chemicals, suitable $\mathrm{pH}$ for UF resin to cure is between $\mathrm{pH}$ 4-5. This is probably the reason why UF-resin mixed with MAP at $\mathrm{pH} 4$, achieved shorter curing time compared with the one that had been mixed with $\mathrm{ZBr}$ at $\mathrm{pH} 10$. These results will help to explore potential approaches of modifications of the curing times of $\mathrm{ZBr}$-mixed and MAP-mixed resins to achieve a curing time to a level similar to the controls. The acidity of the fast growing species as shown by the buffering capacity test will definitely reduce the $\mathrm{pH}$ of the resin and further shorten the curing time during the production of particleboard. It is essential to develop method to increase the curing time to prevent insufficient curing of the resin in the particleboard. A potential approach is adding urea into the mixtures. By increasing the alkalinity of the mixtures using urea, curing rate of the mixture could be reduced for MAP-mixed UF resin, thus lengthen the curing time.

The hardener used may have also contributed the variation of the curing time. In the work, hardener was 
added into the mixture before the fire retardants. The hardener is acidic-based. The role of hardener in resin curing is to release $\mathrm{H}^{+}$by reacting with free formaldehyde, which is readily available in the resin. The $\mathrm{H}^{+}$then reacts with $\mathrm{OH}^{-}$to form water (Xing et al., 2006). This consistent with the observation of the existence of water layer on top of the resin mixtures in the test tubes once they were soaked into the boiling water before curing. As the temperature of the resin increase, the water layer was gradually disappeared to the surrounding, hence encouraged the resin to cure. The $\mathrm{H}^{+}$is also known to reduce the $\mathrm{pH}$ of the resin, hence encouraged curing to occur (Xing et al., 2006). It was expected that longer curing time would be recorded for UF resins mixed with $\mathrm{ZBr}$ or MAP, if hardener was not added before the fire retardants were poured in as previously reported (Izran et al., 2009b; Zaidon et al., 2008a; 2008b).

\section{CONCLUSION}

Systematic experimental studies in the study showed that kenaf, S. macrophylla and A. mangium were less sensitive when exposed to alkaline condition than acidic condition. However, S. macrophylla and A. mangium were relatively more sensitive to acid compared with Kenaf. Test on the curing time with fire retardant additives showed that, UF resin reacted more rapidly with MAP than with $\mathrm{ZBr}$. This was probably due to acidity that had been possessed by MAP, according to its $\mathrm{pH}$. Based on the testing results, some potential modifications to improve the curing time were discussed to avoid short curing time to improve the manufacturability of the material systems.

\section{REFERENCES}

Izran, K., A.R. Abdul Malek, M.N. Mohd Yusof, K. Masseat and Z. Ashaari et al., 2009a. Physical and mechanical properties of flame retardant treated Hibiscus cannabinus particleboard. J. Modern Applied Sci., $\quad 3: \quad$ 2-8. http://www.ccsenet.org/journal/index.php/mas/artic le/viewFile/3503/3180
Izran, K., A. Zaidon, A.R. Abdul Malek, F. Abood and M.J. Saad et al., 2009b. Water absorption and curing time performance of urea formaldehyde resin mixed with different amount of phosphorousbased fire retardants. J. Borneo. Sci., 23: 75-80. http://wwwsst.ums.edu.my/data/file/X8tmhUCg48 x6.pdf

Paridah, M.T., A.M.E. Chin and A. Zaidon, 2001. Bonding properties of Azadirachta excelsa. J. Trop. For. $\quad$ Prod., 7: 161-171. http://direct.bl.uk/bld/PlaceOrder.do?UIN=116865 816\&ETOC $=$ RN\& from=searchengine

Xing, C., S.Y. Zhang, J. Deng and S. Wang, 2006. Urea-formaldehyde-resin gel time as affected by the $\mathrm{pH}$ value, solid content and catalyst. J. Applied Polymer Sci., 103: 1566-1569. DOI: 10.1002/app. 25343

Zaidon, A., A.M. Norhairul Nizam, F. Abood, M.T. Paridah and M.Y. Mohd Nor et al., 2008a. Efficacy of pyrethroid and boron preservatives in protecting particleboards against fungus and termites. J. Trop. For. Sci., 20: 57-65. http://citation.nstl.gov.cn/detail.jsp?internal_id=95 2095

Zaidon, A., F. Abood, A.W. Norhairul Nizam, Y.M. Mohd Nor and M.T. Paridah et al., 2008b. Properties of pyrethoids-treated particleboards manufactured from rubberwood and oil palm Empty Fruit Bunches (EFB). Pertanika J. Trop. Agric. Sci., 21: 171-178. 